\title{
Greenhouse Gas Emission from Solid Waste Disposal Sites in Asia
}

\author{
Tomonori Ishigaki et al. ${ }^{*}$ \\ National Institute for Environmental Studies \\ Japan
}

\section{Introduction}

\subsection{Difficulties in estimating GHG emission from solid waste disposal sites (SWDSs) in Asian countries}

From the viewpoint of sustainable development, appropriate waste management is crucial for conserving the local and global environments. Improvement of waste management in developing countries is directly related to preventing environmental pollution and expanding public health services. Appropriate waste management contributes to reducing not only the emission of water/atmospheric pollutants and odors, but also the emission of greenhouse gases (GHGs). Those involved in international cooperation via technology transfer should take into consideration the potential for shared benefits in terms of "co-benefit" of waste management and climate change. The recent framework of Nationally Appropriate Mitigation Actions (NAMAs) indicated in the Bali Action Plan requires measurability, reportability, and verifiability of emission reduction in mitigation action. Therefore, researchers in the waste management field have focused on finding precise and practical methods for estimating GHG emissions. Solid waste disposal sites (SWDSs) that include both managed landfills and unmanaged dump sites were recognized as major GHG emission sources in developing countries. Although the Intergovernmental Panel on Climate Change (IPCC) released guidelines for estimating GHG emissions, there is still considerable uncertainty regarding emissions from SWDSs in Asian countries, because of the lack of data about the precise emission behavior and waste degradation kinetics, especially at waste disposal sites. In this chapter, authors are going to describe the current situation of the GHG emission estimation and mitigation action in the waste management field in Asia.

\subsection{Current situation of emission estimation methodology}

The continuous compilation of each country's national GHG inventory is very important for understanding the status of the emissions appropriately and considering mitigation actions. However, most Non-Annex I parties cannot compile a national GHG inventory continuously. Therefore, the Greenhouse Gas Inventory Office of Japan (GIO) at the

*Osamu Hirata2 ${ }^{2}$ Takefumi Oda ${ }^{1}$, Komsilp Wangyao $^{3}$, Chart Chiemchaisri" ${ }^{4}$

Sirintornthep Towprayoon ${ }^{3}$,Dong-Hoon Lee ${ }^{5}$ and Masato Yamada ${ }^{1}$

${ }^{1}$ National Institute for Environmental Studies, Japan, ${ }^{2}$ Fukuoka University, Japan, ${ }^{3}$ King Mongkut's University of Technology, Thonburi, Thailand, ${ }^{4}$ Kasetsart University, Thailand, ${ }^{5}$ The University of Seoul, Korea 
National Institute for Environmental Studies (NIES) has held a workshop annually since 2003 (WGIA; the participating countries are Cambodia, China, India, Indonesia, Japan, Korea, Laos, Malaysia, Mongolia, Myanmar, Philippines, Singapore, Thailand, and Vietnam), in collaboration with the activity of the workshop on improvement of solid waste management and reduction of GHG emission in Asia (SWGA), to build the capacity for the compilation of inventories in NA I countries in Asia.

At the 8th workshop of WGIA, held in July 2010, the secretariat conducted a survey by questionnaire to assess the current status of waste sector inventory in each country, and the results were shared in the waste sector working group session [Proceedings of the 8th Workshop on Greenhouse Gas Inventories in Asia (WGIA8), 2010]. Based on the survey results, we report the current status of inventory compilation for SWDS.

\subsubsection{Documentation}

The establishment of a common set of categories by emission source is very helpful for the comparison of countries' emissions by activity. Most of the countries estimate the GHG emissions for the categories in line with IPCC Guidelines. Most of the countries estimate the emissions using a consistent methodology and prepare the documentation describing their estimation methodology in the form of technical reports in the mother tongue and /or English, which is important to maintain its transparency.

In the estimation of GHG emissions, the Common Reporting Format (CRF) tables are a very helpful means for comparing GHG emissions and methodology by source among countries all over the world, and they are also a useful tool for verifying the completeness of emissions estimation. For that reason, several countries have generated CRF tables for their inventories, although there are no obligations to prepare these tables for the NA I countries. Instead of the CRF tables, or in parallel with them, several countries estimate emissions with the UNFCCC software for NA I countries.

\subsubsection{Methodology}

The level of estimation methodologies differs among the parties; for some countries, a simple method is used, and for some countries, a high-tier methodology with countryspecific parameters is employed.

Cambodia, Indonesia, Malaysia, Mongolia, and Vietnam estimated potential emissions with the simple mass balance method (Tier 1) of IPCC methodology. China, Japan, Philippines, and Thailand employed the first-order decay (FOD) model to estimate emissions. Korea was attempting to employ the FOD model at the current situation.

In addition to the subcategory "Managed Disposal Site" or "Unmanaged Disposal Site" used by all of the countries, Indonesia added the country-specific subcategory "EFB solid waste - CPO mills" as another subcategory.

\subsubsection{Activity data}

Only a few parties completed sufficient time series analysis of the amount of final disposal to estimate emissions using the FOD method. Korea has maintained waste statistics since 1990, China has maintained statistics since 2000, and China has estimate activity data prior to 2000 using several drivers.

In many cases, there are insufficient data about the amount of final disposal to estimate emissions from SWDSs, especially from unmanaged disposal sites. Due to the lack of data 
for unmanaged disposal site, for some parties, emission estimates from this category are incomplete.

To resolve such problems of data collection, the all parties have been in the process of conducting a study to look for solutions. As an example of ensuring time series consistency for the amount of waste disposal, they are planning on referring to population statistics and waste generation ratio per person.

Sharing the experience, information, and knowledge regarding data collection methodology at workshops, such as those given by SWGA and WGIA, Asian countries have to make an effort to improve the inventory compilation.

\subsection{Preparation of a GHG inventory and national communications}

The participating countries have finished the waste sector inventory compilation included in the National Communications (NC), and most countries have completed the Second NC (SNC) to be submitted to the UNFCCC secretariat by the end of 2010. Myanmar will submit their NC for the first time. Korea already submitted the SNC in 2003.

Compilation of inventory requires the completion of many processes, such as data collection, verification of the methodology, coordination among relevant agencies, conducting surveys, and so forth. Therefore, it requires the establishment of well-resourced inventory compiling and/or a confirmation agency and the participation of specialized agencies in the inventory compilation processes by category. In each participating country, a specific agency, such as a government agency, university, research institute, and/or temporal project team took charge of inventory compilation in the waste sector (Table 1). Also, each participating country has established a compilation system to support inventory confirmation.

For the current status of national systems, Japan, Korea, Malaysia, Philippines, and Thailand expressed that they would continuously prepare their inventories. Mongolia and Vietnam reported that temporary project teams had compiled SNCs. The remaining countries responded negatively because of the following problems:

- No legal obligation to compile inventories

- Lack of human resources

- $\quad$ Lack of budget

- $\quad$ Lack of an inventory calculation system

- $\quad$ Lack of time

\section{Specific parameters for emission estimation from SWDSs in Asia}

\subsection{First-order decay (FOD) model and the waste degradation rate constant (k)}

The main problem of modelling landfill gas (LFG) generation is not only forecasting the amount of LFG that will be produced, but also the rate and the duration of the production [Augenstein and Pacey, 2001]. Recently, some models have been introduced to estimate the LFG generation rate of landfills. Among them, the FOD model is generally recognized as being the most widely used approach, as it was recommended by the IPCC in the 2006 IPCC Waste Model and by the U.S. Environmental Protection Agency in the LandGEM Model for calculating methane emissions from landfills [IPCC, 2006; USEPA, 1998].

The $\mathrm{k}$ value determines the degradation rate of refuse in the landfill. The higher the value of $\mathrm{k}$, the faster the total methane generation at a landfill increases (as long as the landfill is still receiving waste) and then declines over time after the landfill closes. The value of $\mathrm{k}$ is a 


\begin{tabular}{|c|c|c|c|c|}
\hline \multirow[b]{2}{*}{ Countries } & \multicolumn{3}{|c|}{ Responsible Organization or Agency } & \multirow[b]{2}{*}{$\begin{array}{l}\text { Compilation } \\
\text { system }\end{array}$} \\
\hline & $\begin{array}{l}\text { Government or } \\
\text { relevant agency }\end{array}$ & $\begin{array}{l}\text { University or } \\
\text { research } \\
\text { institute }\end{array}$ & $\begin{array}{l}\text { Temporary } \\
\text { project team }\end{array}$ & \\
\hline Cambodia & ○ & & & ○ \\
\hline China & & ○ & & o \\
\hline India & NA & NA & NA & NA \\
\hline Indonesia & $\circ$ & & & \\
\hline Japan & & o & & ○ \\
\hline Korea & ○ & & & $\circ$ \\
\hline Laos & NA & NA & NA & NA \\
\hline Malaysia & ○ & & & o \\
\hline Mongolia & ○ & & o & ○ \\
\hline Myanmar & NA & NA & NA & NA \\
\hline Philippines & & ○ & & $\circ$ \\
\hline Singapore & NA & NA & NA & NA \\
\hline Thailand & ○ & $\circ$ & & $\circ$ \\
\hline Vietnam & $\circ$ & & ○ & $\circ$ \\
\hline
\end{tabular}

Table 1. Responsible agency

function of the following factors: (1) refuse moisture content, (2) availability of nutrients for methane-generating bacteria, (3) $\mathrm{pH}$, (4) temperature, (5) composition of waste, (6) climatic conditions at the site where the disposal site is located, (7) structure of the SWDS, and (8) waste disposal practices [IPCC, 2006; Pierce, 2005].

In the U.S., regulations under the Clean Air Act suggest a default $\mathrm{k}$ value of $0.05 \mathrm{yr}^{-1}$ for conventional MSW landfills, except for landfills in dry areas where the recommended default $\mathrm{k}$ is $0.02 \mathrm{yr}^{-1}$. An additional set of default values is provided based on emission factors in the U.S. EPA's AP-42, which are a k value of $0.04 \mathrm{yr}^{-1}$ for developing estimates for emission inventories that are considered more representative of MSW landfills where no leachate recirculation is practiced [USEPA, 1997; Thorneloe, 1999]. However, in the case of wet landfill or bioreactor landfill, where leachate recirculation is applied, Faour et al. [2007] analyzed the available recovered landfill gas from wet landfills in order to estimate the gas emission parameters for wet landfills. They found that conservative LandGEM parameters for gas collection at wet landfills suggested a $\mathrm{k}$ value of $0.3 \mathrm{yr}^{-1}$. In Southeast Asia, there were some studies investigating the $\mathrm{k}$ value by using the pumping test and the surface flux measurement. The pumping test from a landfill gas recovery project in Thailand showed that the $\mathrm{k}$ value was $0.32 \mathrm{yr}^{-1}$, which was close to the obtained $\mathrm{k}$ value from the surface flux measurement $\left(0.33 \mathrm{yr}^{-1}\right)$ [Wang-Yao et al, 2004; 2010]. In Vietnam, by using surface flux measurement, it was found that the $\mathrm{k}$ value was $0.51 \mathrm{yr}^{-1}$ [Ishigaki et al., 2008]. The high content of rapidly degradable organic carbon combined with high leachate levels in the waste body might be the main reason for the specifically high degradation rate in these reports [Wangyao et al., 2008]. 


\subsection{Gasification ratio $\left(\mathrm{DOC}_{\mathrm{f}}\right)$}

The gasification ratio is defined as a fraction of the biodegradable carbon to be gasified. At the first stage of degradation, biodegradable carbon in waste should be converted through biological degradation, and normally it will be sequestrated or solubilized. Solubilized carbon will be converted to gas, or discharged from the landfill as leachate. The current default $\mathrm{DOC}_{\mathrm{f}}$ was determined to be half $(50 \%)$ of the biodegradable carbon that will be gasified. The remaining half of the biodegradable carbon is considered to be stored in the SWDS for long term as lignin or humus. For more accurate estimation, separate $\mathrm{DOC}_{\mathrm{f}}$ values should be defined for specific waste types [IPCC, 2006]; for instance $D^{2} C_{\mathrm{f}}$ of wood would be different from that of food. Since the former default $\mathrm{DOC}_{\mathrm{f}}$ was $66 \%$, the $\mathrm{DOC}_{\mathrm{f}}$ value is still under scientific discussion and will likely need revision to reduce the uncertainty. In regions with higher precipitation, anaerobic sanitary landfills should discharge larger amounts of carbons. Matsufuji et al. [1996] reported that SWDSs with a high penetration rate have been found by lysimeter study to leach sometimes more than 10 percent of the carbon in the SWDS. This suggests that $\mathrm{DOC}_{\mathrm{f}}$ in countries with higher precipitation should account for both the carbon storage in the SWDSs and the carbon discharge through leachate.

\subsection{Methane oxidation (OX)}

Up to $50 \%$ of emission reduction of the methane oxidation observed at a landfill surface was achieved with an engineered cover soil structure [Bogner \& Matthews, 2003]. Literature survey conducted by Chanton and Powelson [2009] revealed fraction of methane oxidized ranged from 11 to $89 \%$ with a mean value of $35 \%$. However, the IPCC guidelines recommended a $10 \%$ emission reduction of methane oxidation for managed landfills and a negligible amount for unmanaged SWDSs [IPCC, 2006]. Since most Asian countries lack sufficient scientific proofs for setting country-specific OX values, $0-10 \%$ oxidation as a default value was widely adopted.

Tropical rainfall will affect the methane oxidation by the decrease of gas permeability, and higher temperature will enhance the activity of methanotrophs. Inherently, the percentage of methane oxidation, i.e., OX, will be determined by the balance of the metabolic rate of methanotrophs, methane generation, and oxygen supply into the surface layer of SWDSs. In other words, OX might be partially related to the change of amount of methane emission. This is why it is difficult to set the appropriate OX and is one of the limitations to applying the IPCC Waste Model to Asian SWDSs.

Recent research indicated that nitrous oxide, which is a well-known GHG, must be generated by the activity of methane oxidizing bacteria [Zhang et al., 2009]. Although nitrous oxide generation should be independent from the estimation of methane emission, the total reduction capacity of GHGs should be taken into consideration when introducing methane oxidation technology.

\subsection{The methane correction factor (MCF) and manner of degradation}

The original concept of the MCF was the expression of inhibition of anaerobic waste degradation by the structure and management of waste landfills. Well-managed sanitary landfills were considered to exist under anaerobic conditions, and unmanaged disposal sites were assumed to be partially aerobic because of their lack of covers and/or compaction. In the IPCC guidelines, SWDSs possessing deep layers or high water table were assigned to $20 \%$ inhibition of anaerobic degradation, that is, $20 \%$ aerobic degradation. SWDSs with 
shallow layers were assigned to $40 \%$ inhibition of anaerobic degradation, since the ratio of surface area to total volume of waste is higher in these SWDSs than in other categories of landfill.

Under current practices, semi-aerobical management of landfills will promote aerobic degradation of waste partially thorough passive ventilation. This provided $50 \%$ of inhibition of anaerobic degradation, based on the experimental results reported by Matsufuji et al [1996]. This is an overall estimation of methane emission in semi-aerobic condition compared to that in anaerobic conditions, though the estimation methodology was developed based on anaerobic waste degradation.

Semi-aerobic landfill management was developed in Japan in the 1970s, and many Asian countries have adopted this management concept for their landfills. At unmanaged disposal sites and semi-aerobic landfills, both aerobic and anaerobic degradation will occur simultaneously in a SWDS and should exhibit a specific degradation manner different from that of anaerobic-only degradation. At this moment there is no other good model to express this complicated waste degradation manner. This is a fundamental problem in current emission estimation from the SWDSs in Asia. Further detailed information on semi-aerobic landfill management can be found in later sections.

\section{Emission estimation in new waste management schemes}

\subsection{R activity}

Usually, the reduction, reuse, and recycling (3R) activity in the MSW management treats valuable materials, such as cans, bottles, papers, and plastic packages, in developed countries. However, recycling of these materials by private sectors has already been established in societies in most developing countries, including those in Asia [Wilson, 2009]. Therefore, the target material for $3 R$ in such countries will be garbage or food waste. The first incentive of $3 R$ activity is the reduction of waste disposed in landfill sites. The resource saving and the pollution reduction are the preferred results from $3 R$ activity. The $3 R$ activity of food waste will also result in the reduction of landfilled waste, especially in Asia, where providing enough food to guests is a polite service and/or a symbol of wealth. Since the reduction of landfilled food waste will decrease the degradable organic carbon in landfills, this activity will be a methodology for GHG reduction and also be a part of projects of Clean Development Mechanism (CDM) [Bogner, 2007].

As noted above, 3R activity consists of reduction, reuse, and recycling. Key technologies for the recycling of food waste are composting (or aerobic digestion) and biogas production (or anaerobic digestion). The latter requires a substantial investment to build up the system, including facilities for implementing biogas production. The former, composting, will be the first choice for $3 \mathrm{R}$ activities in most Asian countries. However, it should be noted that some GHGs (methane and nitrous oxide) will be emitted from the process of composting and from farmlands applying the compost [IPCC, 2006].

In all types of waste, recycling is tied to the demand for products. The compost made from food waste should have a quality that meets requests by farmers. A key quality factor for the waste compost will be mixed trashes, such as plastics, metals, glasses, and the like. These materials don't alter the effect of the compost when it is used as fertilizer; however, farmers dislike spreading waste onto their farm land. When the quality of compost produced by food waste does not meet the requests of farmers, it will become waste, be relegated to the landfill, and emit GHGs from the residual biodegradable carbon in the compost. Separation 
of trashes from the food waste is a key technology for the quality control of food waste and compost. In addition to the mechanical biological treatment (MBT) in Europe [Pan, 2007], the segregation of food waste at the source (or home) is a key part of this process. For example, Hanoi city, Vietnam, has been introducing the segregation of food waste at the home into their waste management system to reduce landfilled waste.

The reduction of food waste before generation is the most important of the $3 \mathrm{R}$ activities, as well as other waste. This is challenging, however, because it means asking citizens to make drastic changes in their lifestyle, including changing habits performed historically as part of their culture. In conclusion, determining ways to raise public awareness about the importance of "saving food for the environment" remains an unsolved problem and is the ultimate question that must be answered for the establishment of a sustainable society and GHG reduction.

\subsection{Leachate charge to water body through landfill gas to energy (LFGTE)}

Landfill gas (LFG) is formed as a natural by-product of the anaerobic decomposition of wastes in landfills. Typically, LFG is composed of about $50 \%$ methane, $45 \%$ carbon dioxide, and $5 \%$ other gases, including hydrogen sulfides and volatile organic compounds. LFG is thought to be released from six months to two years after waste is placed in the landfill [U.S. Environmental Protection Agency, 1997]. Methane is a potent GHG, with 21 times the global warming potential of carbon dioxide. LFG can contribute to malodor and present health and safety hazards if it is not well controlled. Many landfill sites have installed LFG recovery and utilization systems or landfill gas to energy (LFGTE) systems to recover the energy value of LFG and to minimize its pollutant effects.

The two common ways to recover LFG are vertical extraction wells and horizontal collectors. The standard and most commonly used is the vertical extraction well. The wells are drilled into the landfill at spacing typically ranging from 45 to $90 \mathrm{~m}$. Pipes 2 to 8 inches in diameter (typically PVC or HDPE) are placed in the holes, which are backfilled with 1inch-diameter, or larger, stones. The pipe is perforated in the lower section where the LFG is collected. Horizontal extraction collectors or trenches may be installed instead of or in combination with vertical wells to collect LFG. They consist of excavated trenches (similar to a pipeline trench) that are backfilled with permeable gravel. Perforated, slotted, or alternating diameters of pipe are installed in the trench. Horizontal extraction collectors are less expensive than vertical extraction wells and are particularly suitable for installation in active filling areas. The advantages of a horizontal extraction collector are low effects from the high leachate level problem in landfill, less obstruction for landfill operations caused by collector headers, and easy installation. The disadvantages of a horizontal extraction collector are high effects from waste settlement and a low recovery efficiency rate per well [The World Bank, 2004].

In tropical countries, the LFG collection system should be used in concert with good leachate management practices. Leachate accumulation within the refuse can dramatically impact the rate of LFG recovery, because liquid in the extraction well and collection trenches effectively restricts their ability to collect and convey LFG [The World Bank, 2004]. In Thailand, field experiences indicate that horizontal extraction collectors are more suitable compared to vertical extraction wells [Eam-O-Ppas and Panpradit, 2003]. The main purpose of using the horizontal extraction well is the very high leachate level in tropical landfills. According to the results of geophysics surveys using the electrical resistivity tomography technique in Thai landfills, the moisture content of waste inside tropical landfills was very 
high. The distributions of high moisture content were found in all parts of the mass of waste, even in areas where the waste had been deposited 3 years previously. The level of leachate was found in the range of 3 to $5 \mathrm{~m}$ beneath the final cover ( 5 to $7 \mathrm{~m}$ above ground level) [Wangyao et al., 2008].

The high level of rapidly degradable organic carbon in the waste stream combined with the high moisture content in the waste body in tropical landfills can stimulate the anaerobic degradation and produce more LFG in a shorter time after the wastes have been deposited. This means that the methane generation rate constant $(\mathrm{k})$ in tropical/wet landfill must be higher than that in dry landfill, which directly affects the LFGTE. Many studies in Asian countries have shown that the $\mathrm{k}$ values are about 0.32 to $0.51 \mathrm{yr}^{-1}$ [Wang-Yao et al., 2004; Wangyao et al., 2010; Ishigaki et al., 2008]. The high $\mathrm{k}$ value also means that the projected period for LFGTE will be shorter than the period for conventional landfills in Europe and the U.S. Moreover, the LFGTE projects in small and medium scale landfills in Asian countries may not be cost effective.

\subsection{Semiaerobic landfill management}

Semiaerobic landfill systems were developed more than 30 years ago and have since then been introduced all over Japan. Nowadays, the characteristics of waste have been changed by the economical situation in many countries and also the technical situation of pretreatment systems of municipal solid waste such as incinerators, mechanical shredders, and so on. However, semiaerobic landfill systems are still being installed in new landfill sites as fundamental technology [Tachifuji, et al., 2009], and are again attracting attention due to the reduction of GHG emissions from lanfill sites in recent years [Matsufuji, et al., 2007].

The main structure of the semiaerobic landfill system is the leachate collection pipe, which is placed on and wrapped by pebbles on the bottom layer. These pipes are linked, with a wide cross-section of pipe ends opened to the air. The most important functions of this pipe are the leachate drainage from the waste layer, and to bring air into the waste layer. The biodegradation process of organic waste can produce heat energy and increase the temperature $\left(50{ }^{\circ} \mathrm{C}\right.$ to $\left.70^{\circ} \mathrm{C}\right)$ of the waste layer. As part of this phenomenon, the air can enter the landfill body naturally by heat recirculation. Both aerobic and anaerobic conditions can be created by the leachate collection pipe in the landfill, and thus both nitrification and denitrification from the leachate can occur.

This system has many advantages, as follows:

1. Cheaper construction and maintenance fee.

2. Less influence on the surrounding environment due the leachate treatment effect.

3. Acceleration of the waste decomposing process by biodegradation due to the increased aerobic bacterial activity.

4. Reduction of water pressure on the bottom liner and prevention of seepage because of rapid draining out of the leachate.

5. Reduction of GHG emissions because of the promotion of aerobic bacterial activity by the expansion of aerobic conditions inside the landfill site.

Recently many countries have started to install this type of landfill system, especially in Asia. This system is a candidate mitigation method for the CDM project, and the new methodology for estimating the emission reduction in semiaerobic landfill projects is waiting for approval by CDM Executive Board of IPCC. 
GHG emissions from semi-aerobic landfill are described by using the structure coefficient, with the MCF estimated as being half as much as that in anaerobic landfills. This effect on the reduction of GHG emissions by semiaerobic landfills is greatly influenced by the amount of passive air introduction into the waste layer. Researchers are currently investigating which parameters have a strong relation to the air inflow rates for improving the aerobic condition in landfill sites. We hope this examination will provide valuable information that will lead to wide acceptance of the CDM project for semiaerobic landfill management.

\subsection{Future trends in national communication and NAMAs}

On a global scale, the waste management sector makes a relatively minor contribution to GHG emissions, estimated at approximately 3-5\% of total anthropogenic emissions in 2005 [Bogner et al., 2007]. The waste sector is considered to be in a unique position to move from being a minor source of global emissions to becoming a major sink of emissions [UNEP, 2010]. While the prevention and recovery of wastes is aimed at avoiding emissions in all other sectors of the economy, the GHG emissions of developing nations are anticipated to increase significantly as better waste management practices lead to more anaerobic, methane-producing conditions in landfills. Therefore, nationally appropriate mitigation actions (NAMAs) have been planned under the specific circumstances of nations. In the present framework under the Kyoto Protocol, CDM had gained initial concerns about mitigating GHG emission. CDM activity in the waste sector has been mainly concentrated on landfill gas capture (where gas is flared or used to generate energy) due to the reduction in methane emissions that can be achieved.

However, it was recognized that under the LFGTE process, fugitive methane leaks from the system also contribute to total GHG emissions from landfills. The climate benefit of this energy generation is attractive in the initial stages though the duration of electricity supply is limited. Furthermore, since most LFGTE projects cannot provide the estimated emission reduction, Asian nations realized the limited possibility of mitigation effect on GHG reduction by insufficient capacity and resources [Ministry of Natural Resources and Environment [MONRE], 2010].

Although the country-specific situation will affect the choice of mitigation option and technologies, the energy production was attracted as the most perspective options on waste-related mitigation as using rice husks to electricity and using biogas to heat and/or electricity [MONRE, 2010; Office of Natural Resources and Environmental Policy and Planning, 2011]. Substitution of raw material by the utilization of industrial or agricultural waste should also be considered, such as using molasses urea to feed dairy cattle [MONRE, 2010]. These mitigation options are focused on the main/important industries in each nation; however, the ripple effect in scale of these mitigations cannot be expected. In contrast, direct measures to improve the waste management should be the fundamental solution to achieve the co-benefit philosophy [Jochem \& Madlener, 2003], such as prohibition of open dumping by 2013 in Indonesia [Hilman, 2010] and solidified fuel production from the refuse [Ministry of Nature, Environment and Tourism, 2010]. In addition, waste management provided also socioeconomic and environmental co-benefit in term of employments and imcomes as well as raising the environmental awareness and standard. In many developing countries proper waste managements the campaign to reduce GHG. In Singapore, limitation of disposal land drove to reduce the waste volume by incineration, simultaneously producing energy (Waste to Energy; WtE). Currently a total of 
four WtE plants in Singapore contribute 3-4\% of the country's electricity supply [National Environmental Agency, 2010].

Mitigation options in the waste sector must be determined based on each country's situation and development policies. The future planning of a nation's energy, primary industry, and manufacturing industry will be key factors when selecting the mitigation actions. The plans must be appropriate, and the technical support by developed countries must also be appropriate with regard to the nation's and world's future.

\section{Conclusion - needs for specific estimation methodology for Asian nations}

Disposal of organic waste is a major source of GHG emissions from the waste sector in Asia. Current estimation schemes for GHG emissions and mitigation at SWDSs were developed in and for Western countries with temperate climates and lower precipitation zones. There are several barriers to applying these to Asian countries with tropical climates and higher precipitation zones. In particular, the basic design of the IPCC Waste Model doesn't fit the unmanaged and managed SWDSs in Asia with their higher water flux, permeable cover, and semi-aerobic configuration. Available measures for the GHG mitigations at SWDSs, including LFGTE and WtE, have also emerged from Western countries, where the social and economic background is quite different from that in Asia. For example, in Asia the higher moisture content of waste, mainly caused by food waste, makes the separation and processing of food waste difficult, and the higher $\mathrm{k}$ value leads to failures of CDM projects of LFGTE. It is need for the Asian countries to establish appropriate estimation schemes for GHG emissions and mitigation that reflect their own situations. CDM and other mechanisms for GHG reduction actively promote several researches, development and projects for GHG mitigation in the waste sector of Asia. These projects, if successful, will release Asia from situations of being "unable to comply because of insufficient information" and reveal measures that are specific and appropriate in Asia. Naturally, appropriate mitigation of GHG emission from organic waste will achieve local environmental protection and $3 R$, that is expressing as the "co-benefit".

\section{Acknowledgment}

The authors thank the Ministry of the Environment, Japan for the financial support through the Global Environmental Research Fund (B-071) and the Environmental Research \& Technology Development Fund (A1001).

\section{References}

Augenstein, D. \& Pacey, J. (1991) Modeling landfill methane generation, Proceedings of the Sardinia 91, Third International Landfill Symposium, Sardinia, Italy.

Bogner, J.; Abdelrafie Ahmed M.; Diaz, C.; Faaij, A.; Gao, Q.; Hashimoto, S.; Mareckova, K.; Pipatti, R.; Zhang, T. (2007) Waste Management, In Climate Change 2007: Mitigation. Contribution of Working Group III to the Fourth Assessment Report of the Intergovernmental Panel on Climate Change [B. Metz, O.R. Davidson, P.R. Bosch, R. Dave, L.A. Meyer (eds)], Cambridge University Press, Cambridge, United Kingdom and New York, NY, USA. 
Bogner, J. \& Matthews, E. (2003). Global methane emissions from landfills: New methodology and annual estimates 1980 - 1996, Global Biogeochemical Cycles, 17, 1065.

Chanton, J.P. \& Powelson D.K. (2009) Methane oxidation ib landfill cover soils, is a $10 \%$ default value resonable?, Journal of Environmental Quality, 38, 654-663.

Eam-O-Ppas, K. \& Panpradit, B. (2003) Landfill Gas Recovery Using Horizontal Collectors in Thailand, Fourth International Conference of the ORBIT Association, Perth, Australia.

Faour, A.A., Reinhart, D.R., \& You, H. (2007) First-order kinetic gas generation model parameters for wet landfills, Waste Management, 27, 946-953.

Greenhouse Gas Inventory Office of Japan, Center for Global Environmental Research, National Institute for Environmental Studies, Japan (2010) Proceedings of the 8th Workshop on Greenhouse Gas Inventories in Asia (WGIA8), -Capacity building for measurability, reportability and verifiability- ISSN 1341-4356

Hilman, M (2010; Ed.) Indonesia Second National Communication under the United Nations Framework Convention on Climate Change.

IPCC 2006 (2006) IPCC Guidelines for National Greenhouse Gas Inventories, Prepared by the National Greenhouse Gas Inventories Programme, Eggleston H.S., Buendia L., Miwa K., Ngara T. and Tanabe K. (eds). Published: IGES, Japan.

Ishigaki, T., Chung, C.V., Sang, N.N., Ike, M., Otsuka, K., Yamada, M. \& Inoue, Y. (2008) Estimation and field measurement of methane emission from waste landfills in Hanoi, Vietnam, Journal of Material Cycles and Waste Management, 10, 165-170.

Jochem, E. \& Madlener, R. (2003) The Forgotten Benefits of Climate Change Mitigation: Innovation, Technological Leapfrogging, Employment, and Sustainable Development, OECD Workshop on the Benefits of Climate Policy: Improving Information for Policy Makers.

Matsufuji, Y., Kobayashi, H., Tanaka, A., Ando, S., Kawabata, T. \& Hanashima, M. (1996). Generation of greenhouse gas effect gases by different landfill types and methane gas control, Proceedings of 7th ISWA International Congress and Exhibition, 10, 253$254 .$.

Matsufuji Y. \& Tachifuji A. (2007) Reduction of methane production by semiaerobic landfill, Journal of Japan Waste Management Association, ISSN-0285-4104, p.p 351-356

Ministry of Natural Resources and Environment, Socialist Republic of Viet Nam (2010) Vietnam's Second National Communication to the United Nations Framework Convention on Climate Change.

Ministry of Nature, Environment and Tourism, Mongolia (2010) Mongolia Second National Communication under the United Nations Framework Convention on Climate Change.

National Environmental Agency (2010) Singapore's Second National Communication under the United Nations Framework Convention on Climate Change

Office of Natural Resources and Environmental Policy and Planning, Ministry of Natural Resources and Environment (2011) Thailand's Second National Communication under the United Nations Framework Convention on Climate Change.

Pan, J. L. \& N. Voulvoulis (2007) The role of mechanical and biological treatment in reducing methane emissions from landfill disposal of municipal solid waste in the United Kingdom, Journal of the Air \& Waste Management Association 57(2): 155-163.

Pierce, J., LaFountain, L., \& Huitric, R. (2005) Landfill Gas Generation E Modeling Manual of Practice, SWANA. 
Tachifuji, A. \& Hirata, O. (2009) The Challenge of Overseas Technology Transfer Based on the Semi-aerobic Landfill System (Fukuoka Method), Material Cycles and Waste Management Research, ISSN 1883-5864, p.p 308-313

Thorneloe, S.A., Reisdorph, A., Laur, M., Pelt, R., Bass, R.L. \& Burklin, C. (1999) The US Environmental Protection Agency's Landfill Gas Emissions Model (LandGEM), Proceedings of Sardinia 99 Sixth International Landfill Symposium, IV - Environmental Impact, Aftercare and Remediation of Landfills, 11-18.

The World Bank (2004) Handbook for the Preparation of LFG to Energy Projects in Latin America and the Caribbean, Available online at: www.bancomundial.org.ar/lfg

U.S. Environmental Protection Agency (1997) Opportunities for Landfill Gas Energy Recovery in Colorado, EPA 430-B-97-036, Washington, DC: EPA.

USEPA (1997) Compilation of Air Pollution Emission Factors, AP-42, fifth ed. Supplement C. Office of Air Quality Planning and Statistics, Research Triangle Park, NC.

USEPA (1998) Landfill Air Emissions Estimation Model (Version 2.01), EPA-68-D10117, EPA 68-D3-0033, US Environmental Protection Agency.

UNEP (2010) Waste and Climate Change; Global Trends and Strategy Framework

Wang-Yao, K., Towprayoon, S. \& Jaroenpoj, S. (2004) Estimation of Landfill Gas Production Using Pumping Test, The Joint International Conference on "Sustainable Energy and Environment (SEE)" Hua Hin, Thailand.

Wangyao, K., Yamada, M., Endo, Ishigaki, T., Naruoka, T., Towprayoon, S., Chiemchaisri, C. \& Sutthasil, N. (2010) Methane Generation Rate Constant in Tropical Landfill, Journal of Sustainable Energy and Environment, 1 (4), 181-184.

Wangyao, K., Yamada, M., Suanburi, D., Endo, K., Ishigaki, T and Isobe, Y. (2008) Effect of leachate distribution on methane emissions in tropical landfill. The 5th Asian-Pacific Landfill Symposium, Sapporo, Hokkaido, Japan.

Wilson, D. C., A. O. Araba, K. Chinwah \& C. R. Cheeseman (2009) Building recycling rates through the informal sector. Waste Management 29(2): 629-635.

Zhang, H., He, P. \& Shao, L. (2009) $\mathrm{N}_{2} \mathrm{O}$ emissions at municipal solid waste landfill sites: Effects of $\mathrm{CH}_{4}$ emissions and cover soil, Atmospheric Environment, 43, 2623-2631. 


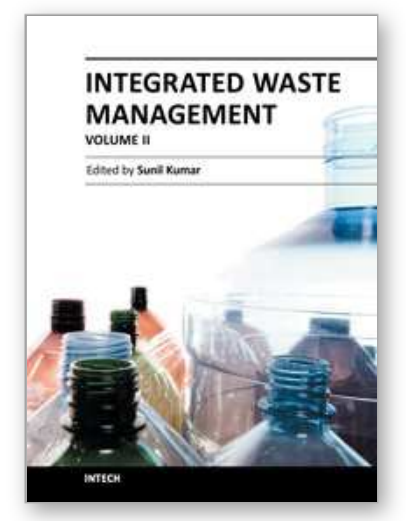

\author{
Integrated Waste Management - Volume II \\ Edited by Mr. Sunil Kumar
}

ISBN 978-953-307-447-4

Hard cover, 472 pages

Publisher InTech

Published online 23, August, 2011

Published in print edition August, 2011

This book reports mostly on institutional arrangements under policy and legal issues, composting and vermicomposting of solid waste under processing aspects, electrical and electronic waste under industrial waste category, application of GIS and LCA in waste management, and there are also several research papers relating to $\mathrm{GHG}$ emission from dumpsites.

\title{
How to reference
}

In order to correctly reference this scholarly work, feel free to copy and paste the following:

Tomonori Ishigaki, Osamu Hirata, Takefumi Oda, Komsilp Wangyao, Chart Chiemchaisri, Sirintornthep Towprayoon, Dong-Hoon Lee and Masato Yamada (2011). Greenhouse Gas Emission from Solid Waste Disposal Sites in Asia, Integrated Waste Management - Volume II, Mr. Sunil Kumar (Ed.), ISBN: 978-953-307447-4, InTech, Available from: http://www.intechopen.com/books/integrated-waste-management-volumeii/greenhouse-gas-emission-from-solid-waste-disposal-sites-in-asia

\section{INTECH}

open science | open minds

\author{
InTech Europe \\ University Campus STeP Ri \\ Slavka Krautzeka 83/A \\ 51000 Rijeka, Croatia \\ Phone: +385 (51) 770447 \\ Fax: +385 (51) 686166 \\ www.intechopen.com
}

\author{
InTech China \\ Unit 405, Office Block, Hotel Equatorial Shanghai \\ No.65, Yan An Road (West), Shanghai, 200040, China \\ 中国上海市延安西路65号上海国际贵都大饭店办公楼 405 单元 \\ Phone: +86-21-62489820 \\ Fax: $+86-21-62489821$
}


(C) 2011 The Author(s). Licensee IntechOpen. This chapter is distributed under the terms of the Creative Commons Attribution-NonCommercialShareAlike-3.0 License, which permits use, distribution and reproduction for non-commercial purposes, provided the original is properly cited and derivative works building on this content are distributed under the same license. 